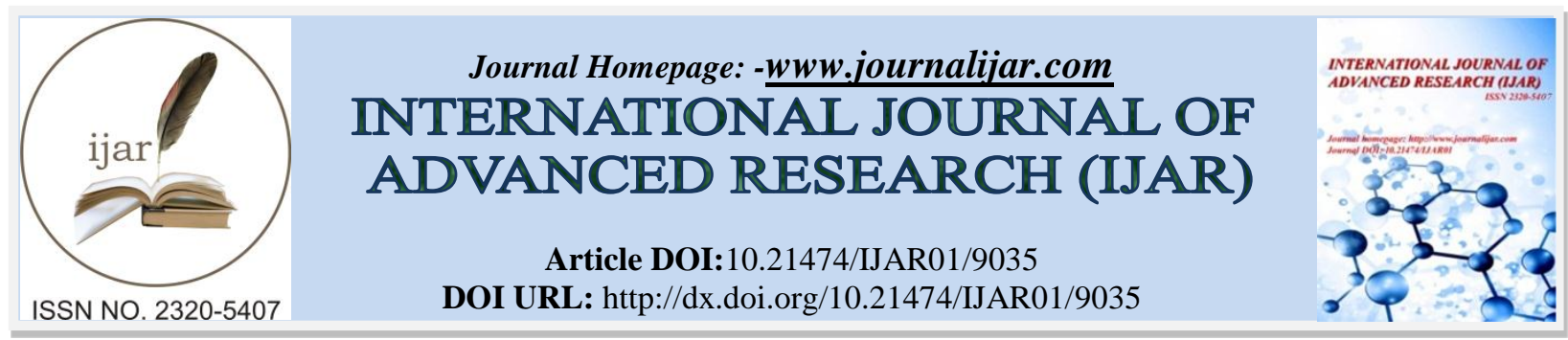

RESEARCH ARTICLE

\title{
THEORETICAL AND LEGAL ANALYSIS OF LICENSING SYSTEM OF THE REPUBLIC OF UZBEKISTAN.
}

\author{
Selimanova Svetlana Mikhaylovna. \\ Academy of the Ministry of Internal Affairs of the Republic of UzbekistanDoctor of law sciences (DSc), Associate \\ professor.
}

\section{Manuscript Info}

Manuscript History

Received: 08 March 2019

Final Accepted: 10 April 2019

Published: May 2019

Key words:-

licensing system, license, licensed

activities, types of licenses, licensing

authorities, license applicants.

\section{Abstract}

The article analyzes the theoretical and legal foundations of the licensing system of the Republic of Uzbekistan, formulates theoretical and practical conclusions, and offers suggestions for its improvement.

Copy Right, IJAR, 2019,. All rights reserved.

\section{Introduction:-}

In the world the special attention is given to enhancement of application of means of administrative legal regulation of the state, in particular the importance is given to ensuring transparency of processes of licensing, optimization of their forms and terms of consideration, simplification of procedures of licensing, unification of the licensed types of activity, expansion of methods of protection of the rights and interests of job seekers of the license and licensees, decentralization of functions of issue of licenses, implementation of modern information and communication technologies in licensing processes.

For years of independence for the purpose of legal regulation of the licensed relations about hundred regulatory legal acts in which were established an order, conditions, requirements, procedures of licensing, types of the licensed activities were adopted. The allowing documents and license types inappropriate to modern requirements were cancelled and also allowing procedures are optimized.

Licensing is recognized important means of the administrative legal regulation guaranteeing safety of goods, works and services on an equal basis with its reforming the world, and also for the purpose of providing the rights and interests of job seekers of licenses and licensees search of the scientific problem resolution of optimization of spheres of influence of functions of state regulation, including to reducing the licensed types of activity, enhancement of processes of licensing, development of criteria of reference of a type of activity to licensed, to determination of the directions and forms of implementation of public control over observance of licensed requirements and conditions is important.

On the basis of the conducted research claims that the social and economic relations, business activity, an authorization system, questions of licensing are so closely interconnected and interdependent, and also are bound among themselves that separately to consider and analyze their condition, legal regulation and the prospects of development allocating only system of licensing it is impossible. By consideration of licensing it is necessary to consider a licensing ratio with institutes of permission, registration, quoting, accreditation, certification,

Corresponding Author:-Selimanova Svetlana Mikhaylovna.

Address:-Academy of the Ministry of Internal Affairs of the Republic of UzbekistanDoctor of law sciences (DSc). Associate professor. 
admission, etc. as similar special administrative legal regimes regarding their unification and an exception of barriers to development of business activity and reducing state regulation in the specified spheres.

The authorization system and licensing correspond as a part and whole. They are identical in essence, but are various on subjects. The authorization system is a form of the state control of legality of expected actions of the citizen or the organization, its task - permission to make only certainly lawful acts and refusal in making of actions illegal.

Permission on the essence is method of legal regulation by the state social эконмических processes and reflects in itself a between the permitted and forbidden behavior, includes a complex of methods of the regulating impact of state bodies on the social and economic relations sent for approval, registration, obtaining of forms of permissions.

Entering of licensing in the Republic of Uzbekistan is caused by changes in nature of impact of the state on the public relations developing in the field of economy and social development. Getting into many spheres of productive and social activity, it gives the chance to observe balance of consumer interests, entrepreneurs and other subjects, on the one hand, and the states on the other hand.

Separate types of activity subjects to licensing are determined by the Resolution Oliy Mazhlis of the Republic of Uzbekistan «About the list of types of activity on which implementation licenses» of May 12, 2001 and the Resolution of Cabinet council of the Republic of Uzbekistan «About measures for implementation of the Law of the Republic of Uzbekistan «About licensing of separate types of activity» of June 28, 2001 are required.

The relations arising in case of export licensing and commodity import (works, services) are regulated by Regulations on an order of export licensing and import of specific goods in the territory of the Republic of Uzbekistan the approved Ministry of Foreign Economic Relations, the Ministry of Finance, the State Customs Committee and approved with the Central Bank of the Republic of Uzbekistan.

The relations arising when licensing use of intellectual property items and also under the agreement of the complex entrepreneurial license (the agreement on franchizing) are regulated by chapter 50 («The complex entrepreneurial license»), and also article 1036 of the Civil code of the Republic of Uzbekistan.

Besides studying of the legislation showed licensing of on right to use by subsoil plots is regulated by the Resolution of the President of the Republic of Uzbekistan «About approval of a regulations on an order of issue of licenses for right to use by the subsoil plots containing nonmetallic minerals».

Basic concepts of system of licensing is performed and it is administrative - the legal nature of system of licensing. So according in the conditions of the social and economic reforms undertaken in the Republic of Uzbekistan and also in democratization process and a humanization of public life strengthening of legality and law and order, ensuring reliably guaranteed protection of constitutional rights and freedoms of citizens, interests of the state and society in general is of particular importance. As it stands system of licensing in our country I appeared rather recently and the fact that its theoretical base isn't developed adequately is explained by it.

The system of licensing consists of such institutes as the license, the licensed type of activity, licensing, licensed requirements and conditions, licensing authorities, the job seeker of the license, the licensee, the license agreement, the register of licenses, etc.

The author formulated concepts the license and licensing: The license is the document certificating the right of the licensee to implementation of the licensed type of activity, issued by the authorized (licensing) bodies for a certain term or is termless. «Licensing is the administrative and legal method of state regulation of the economic relations representing establishment of an order of receipt of special permission (license) for occupation separate types of activity which implementation can cause damage to interests of the personality, society, state and a homeland security.

Licensing, prolongation of term of its action, suspension, prolongation, the termination, cancellation of the license are legal reflection of the actions performed in the course of licensing which as well as control of licensed bodies of observance of licensed conditions and requirements are regulated by precepts of law. Proceeding from it, all above- 
mentioned relations are legal, and set of the precepts of law governing the above-stated relations constitute system of licensing.

Thus, it is necessary to recognize that state policy in the sphere of licensing is a method of public administration in the field of licensing, representing the controlling beginning and also organizing and regulating the impact of the state on public activity of people for the purpose of its streamlining, preserving or transformation relying on its imperious force.

Multidimensional nature of licensed activity is shown that it can be considered in various forms and as a method of a management activity, and as the instrument of safety of society and state from activities which can entail causing damage to society and state and as a method of public administration.

In the third paragraph classification of the licensed types of activity on the basis of their administrative legal regulation is performed. For years of independence in the Republic of Uzbekistan it is created and the legal base of the economic relations in the form of the laws and regulatory legal acts governing the public relations in the sphere of business activity is constantly enhanced.

According to Art. 7 of the Law of the Republic of Uzbekistan «About licensing of separate types of activity» types of activity which implementation can entail causing damage to the rights and legitimate interests, health of citizens, public safety and which regulation can't be performed by other methods, except as licensing belong to the licensed types of activity.

Proceeding from the above classification it is possible to draw a conclusion that licensing is one of methods of administrative and legal impact of the state not only on economic processes, and on the public relations in the sphere of providing the rights and personal freedoms, health of citizens, public order and safety, moral foundations of society, spirituality and morality, an economic, ecological, information, technical, homeland security.

The upgrade of the legislation which is carried out for years of independence allowed to test new a method of the right regulation in the field of licensing of separate types of activity and in a complex to consider experience of lawenforcement practice in the field of licensing.

The license is the official document which permits to perform the licensed type of activity in case of obligatory observance of the licensed requirements and conditions issued by the licensing body to legal entities and physical persons.

Proceeding from the aforesaid it is necessary to recognize that in the conditions of upgrade of the country the deep legal analysis and search of solutions of problems of reforming of a permit system in general is necessary. It also proceeds from those realities and the developing situation, taking into account the carried-out large-scale basic changes which happened in the administrative legislation in connection with liberalization of a judicial system of law. They showed that the system of licensing in our country sharply feels the need for unification of regulations of the legislation for the sphere of the licensing provided today in more than fifty regulatory legal acts. Besides, it is necessary to provide measures for enhancement, democratization of procedural mechanisms of licensing, law enforcement, reliable protection of subjects of business and the rights of a private entrepreneurship, the deep analysis and radical review of the legislation on licensing is required that assumes a complete inventory of all regulatory legal acts regulating the licensed relations. It to the same extent concerns both material, and procedural rules.

The law of the Republic of Uzbekistan «About licensing of separate types of activity» of May 25, 2000 is the main regulatory legal act regulating the relations connected with licensing of separate types of activity. The legislation on licensing represents an extensive network of the interconnected regulatory legal acts about licensing now. The basis of the legislation on licensing is constituted by the Law «About Licensing of Separate Types of Activity» of May 25,2000 .

The main feature of a permit system is that in the legislation rules about a possibility of entering of licensing of new types of activity only by entering of additions into the list of types of activity provided by the resolution of Cabinet council of the Republic of Uzbekistan on which implementation licenses are required are established. Thus, it is 
cleared up a question of need of licensing of these or those types of activity. The unique possibility of existence out of legislative rule-making in the sphere of licensing - regarding the types of activity listed normal to the p. 3 of Art. 2 of the Law of the Republic of Uzbekistan «About licensing of separate types of activity» of May 25, 2000 as the Law doesn't extend to them.

It is also necessary to notice that other mass of the legislation draw up standardly legal acts of the Office of the Republic of Uzbekistan and departmental regulatory legal acts of licensing authorities. At the same time the number of regulatory legal acts exceeds 50 units among which the legal acts establishing licensing of this or that type of activity from among listed in the Resolution of Cabinet council of the Republic of Uzbekistan «About measures for implementation of the Law of the Republic of Uzbekistan «About licensing of separate types of activity» prevail. So, provisions about licensing of activities in the sphere of customs affairs are enshrined in the Customs code of the Republic of Uzbekistan, the Law of the Republic of Uzbekistan «About conservation» of December 9, 1992; The law of the Republic of Uzbekistan «About advertising» of December 24, 1998, the Law of the Republic of Uzbekistan «About an author's right and the neighboring rights» of July 20, 2006, and also in regulations on licensing of separate types of activity. Besides among the legal acts regulating the licensed relations it should be noted the instructions and orders of the Central bank of the Republic of Uzbekistan devoted to licensing of banking activity.

Licensed activity in the conditions of forming of the market relations has important social and economic, legal and managerial value.

Based on our comprehensive study of the administrative and legal aspects of the licensing system in the Republic of Uzbekistan, we came to the following theoretical conclusions and proposals for improving the licensing system:

1. a research of theoretical bases of licensing the author's definition of a concept of licensing «Licensing is developed it is the administrative and legal method of state regulation of the economic relations representing establishment of an order of receipt of special permission (license) for occupation separate types of activity which implementation can cause damage to interests of the personality, society, state and a homeland security».

2. on the basis of the inventory of normative legal acts carried out in the theses and for their systematization and reduction in uniform system it is necessary to develop the uniform list of the licensed kinds of activity.

3. it is necessary to include all types of licenses of export and import of specific goods, the right of use of the subsoil plots and subsoil plots containing nonmetallic minerals in it;

4. determine the licensing bodies to each of them; adopt the separate resolutions regulating the order of licensing of the specified kinds of activity. 